\title{
Rapid Screening of Berseem Clover (Trifolium alexandrinum) Endophytic Bacteria for Rice Plant Seedlings Growth-Promoting Agents
}

\author{
H. Etesami, H. Mirsyedhosseini, and H. A. Alikhani \\ Department of Soil Science, College of Agriculture \& Natural Resources, Tehran University, Karaj 31587-77871, Iran \\ Correspondence should be addressed to H. A. Alikhani; halikhan@ut.ac.ir
}

Received 13 April 2013; Accepted 28 May 2013

Academic Editors: G. Benckiser, L. A. Dawson, J. A. Entry, D. Jacques, and D. Lin

Copyright (C) 2013 H. Etesami et al. This is an open access article distributed under the Creative Commons Attribution License, which permits unrestricted use, distribution, and reproduction in any medium, provided the original work is properly cited.

A simple screening method to detect berseem clover (Trifolium alexandrinum) endophytic bacteria for rice plant growth-promoting agents on the basis of a root colonization bioassay and a plant growth promoting trait is characterized. Firstly, 200 isolates (80 endophytes and 120 rhizospheric isolates) isolated from berseem clover were inoculated as 10 mixtures of 20 strains each on two rice varieties under gnotobiotic conditions. Then, the reisolated endophytic strains from two rice varieties were characterized for plant growth promoting (PGP) traits. Secondly, the colonization and growth promoting effects of endophytic strains were compared in inoculated rice plantlets as single-strain inoculants. A significant relationship among indole-3-acetic acid (IAA) producing isolates, the size of root colonization, and plant growth was observed. Our results suggest that the ability of IAA production by the endophytic bacteria which may have a stimulatory effect on plant development may be the first plant growth promoting trait for screening bacteria isolated from clover plant for rice plant growth promoting agents. In addition, this study indicates that the selected bacterial isolates based on their IAA producing trait have the potential for PGP and more colonization of rice plant.

\section{Introduction}

Research into how plant growth can be promoted has mainly concentrated on rhizobacteria. More recently, however, attention has been focused on the plant growth-promoting capacity of endophytes [1]. The study of plant bacterial endophytes is important for understanding ecological interactions and to develop biotechnological applications. Endophytic bacteria can be defined as those bacteria that can colonize the internal tissue of the plant without showing negative symptoms on their host [2]. Endophytes promote the growth of plants in various ways, for example, through secretion of plant growth regulators, such as indole-3-acetic acid (IAA) [3], via phosphate solubilizing activity [4], by enhancing hyphal growth and mycorrhizal colonization [5], production of siderophores [6], and supplying biologically fixed nitrogen [7]. In addition, endophytic bacteria supply essential vitamins to plants [7]. The production of auxin-like compounds increases seed production and germination [8] along with increased shoot growth and tillering [9]. Other effects of endophyte infection on the host plant include osmotic adjustment, stomatal regulation, modification of root morphology, enhanced uptake of minerals, and alteration of nitrogen accumulation and metabolism [10]. During the last few years, there has been an increased interest in exploring the possibility of extending the beneficial interactions between rice and some of plant growth-promoting bacteria including $\mathrm{N}_{2}$-fixing bacteria. Many reports found in literature strongly suggest that these endophytes have an excellent potential to be used as plant growth promoters with legumes and nonlegumes [11]. Yanni et al. [12] showed that rhizobia can naturally colonize the interior of rice roots rotated with clover berseem and assessed the potential impact of this novel plant-microbe association on rice production. In Iran, the second cropping in rotation with rice is berseem clover. Our interest has been to assess the possible existence and agronomic importance of naturally occurring endophytes within rice roots in Iran where rice production is significantly 
benefited by rotation with berseem clover that could sustain the populations of the corresponding bacteria at a high inoculum potential for the next rice growing season. PGB traits can be assessed under laboratory conditions and allow the selection of strains that could lead to increased plant growth [12]. Nature selects endophytes that are competitively fit to occupy compatible niches within this nutritionally enriched and protected habitat of the root interior without causing pathological stress on the host plant. But when we intended to screen these bacteria for other plant growth-promoting agents, it is better to screen these bacteria for achieving the most promising isolates having suitable colonization and plant growth-promoting traits. In most researches, it has been seen that, following incubation, bacterial flora are taken at random from Petri plates or morphological representatives are selected for further study. But this type of selection may remove some superior bacteria regarding plant growthpromoting traits and with high colonization ability. The Gram reaction test and other phenotypic characteristics could not definitively determine the classification for the isolates. So, it is essential to study all the bacteria isolated in an economic way. On the other hand, if we test all strains for all PGP traits, this process will take a long time and will be costly. Since the ability to colonize roots is a necessary condition for a rhizobacteria to be considered a true plant growth-promoting rhizobacteria (PGPR) [13], we would not need to identify the PGP traits of all of the isolates, just those that are able to establish themselves in rice roots. In addition, the first screening on the basis of the most promising PGP traits is very important and economic too. So, we were interested in finding an important auxiliary tool for helping in selection of the isolates with colonization and PGPR potentiality. Yanni et al. [12] showed that in spite of developing higher populations within roots of Indica rice, the endophytic bacteria elicited higher short-term PGP responses on the Japonica rice. They indicated that identification of superior combinations of rhizobia and rice genotypes for optimal growth responses will likely require PGP bioassays rather than just an assessment of the bacterial endophyte's ability to colonize the root interior, and manipulations to increase the endophyte population above the natural level achievable within rice per se may not necessarily improve the resultant growth promotion response. Several methods have been used to demonstrate that root colonization is taking place, including use of fluorescence techniques, antibiotic-resistant mutants, and marker genes, such as LUX and GUS. However, these methods are relatively expensive and time consuming $[13,14]$.

Hence, the present study was undertaken to (i) isolate indigenous endophytic and rhizoshpere isolates from berseem clover plants grown in rotation with rice plants, (ii) evaluate which bacteria can colonize the endophytic sites of two rice varieties by batch inoculations onto rice in the presence of low or moderate levels of $\mathrm{N}$ under gnotobiotic conditions, (iii) evaluate the PGP traits of the isolates, (iv) reapply the endophytic isolates in single-strain inoculations onto rice in the presence of $\mathrm{N}$ and measure rice growth to evaluate if they promote the growth of the rice, and (v) evaluate efficiency of the relationship between root colonization and the most promising PGP trait on rice seedlings inoculated with endophytic isolates.

\section{Materials and Methods}

2.1. Isolation of Endophytic and Rhizosphere Bacteria. Rhizosphere soil and roots of the berseem clover plants (Trifolium alexandrinum) were collected from the Dashte naz Research Farm, Māzandarān Province, Iran. Bacterial endophytes were isolated based on the method described by the Sturz et al. [15]. Plants (at flowering) were collected randomly from a field plot where rice has been rotated with clover and conveyed to the laboratory in coolers. Roots were washed thoroughly with tap water, rinsed with deionized water, and drained on absorbent towels. Roots were cut into $2-3 \mathrm{~cm}$ long slices with a sterile scalpel, and ten grams of roots was shaken for 30 minutes in $500 \mathrm{~mL}$ Erlenmeyer flask containing $250 \mathrm{~mL}$ sterile deionized water and 25 grams of glass beads. Clover roots were washed in running tap water and commercial detergent to remove soil and then rinsed for $30 \mathrm{~s}$ in a $95 \%$ ethanol solution. Surface sterilization was with $10 \%$ sodium hypochlorite solution for $4 \mathrm{~min}$, followed by three rinses in sterile distilled water. Aseptic technique was used in every part. Root slices were placed in a sterilized commercial blender in quarter-strength Ringer's solution and macerated for $3 \mathrm{~min}$. The macerate was decanted into conical flasks, shaken on a wrist-action shaker for $45 \mathrm{~min}$, a dilution series made and the diluent plated onto tryptic soy agar (TSA). For isolating rhizosphere bacteria, soil adhered to roots was collected. After proper mixing, $10 \mathrm{~g}$ of soil was transferred to a $250 \mathrm{~mL}$ Erlenmeyer flask containing $90 \mathrm{~mL}$ sterile distilled water and shaken $(120 \mathrm{rpm})$ for $30 \mathrm{~min}$. Serial dilutions (up to $10^{-7}$ ) were made, and $0.1 \mathrm{~mL}$ aliquots were spread on to TSA plates. All the plates were incubated at $28^{\circ} \mathrm{C}$ for $3-5$ days at which time the number of colonyforming units (cfu) was counted. Numbers of endophytic bacteria cells recovered were expressed as $\mathrm{cfu} \mathrm{g}^{-1}$ fresh tissue weight. Three replicates per dilution were made. To confirm that the surface-sterilization process was successful, tissue pieces were pressed onto or rolled over TSA, and aliquots of water from the final rinse solutions were plated onto TSA and tested for contaminants. No contaminants were found, and the surface-sterilization procedure was considered effective. Following incubation of bacterial flora, bacterial isolates identified as individual cfu were selected and subcultured onto TSA. Similar bacterial isolates were grouped on the basis of phenotypic characteristics (shape, motility, color, rate of growth, and culture morphology) and Gram-staining reaction and stored in a refrigerator at $4^{\circ} \mathrm{C}$ for further studies.

2.2. Colonization Assay. We used the method described by Yanni et al. [12] with some modification for colonization assay of rice roots with all the strains isolated from clover plant in presence and absence of nitrogen. Two rice varieties, Khazar a bred variety and Hashemi a nonbred variety obtained from the rice research institute in Iran, both currently cultivated in Māzandarān in rotation with berseem clover, were used for this study. Separate tests were established that the seeds of these two rice cultivars harbored no endophytic bacteria 
that would survive surface sterilization. $8 \mathrm{mM}\left(\mathrm{NH}_{4}\right)_{2} \mathrm{SO}_{4}$ was used in Hoagland's plant growth medium. $100 \mu \mathrm{L}$ of the bacterial inocula grown separately on NB medium for 2 days at $30^{\circ} \mathrm{C}$ was suspended in sterile Hoagland's medium as 10 mixtures of 20 strains each. The mixtures were selected at random. Each seedling root was inoculated with $10^{8}$ cells $\mathrm{mL}^{-1}$ (12 replicates were used for each treatment) and incubated in a growth chamber. Rice plants in culture tubes were gently uprooted 20 days after inoculation and then excised at the stem base. Roots were rinsed free of agar and sand, blotted, weighed, surface-sterilized with $70 \%$ ethanol followed by $10 \%$ sodium hypochlorite solution, rolled over plates of TSA to check for surface sterility, and then macerated in $5 \mathrm{mM}$ Na-phosphate buffer as described above. Viable plate counts of the rice endophyte populations were made after 3 days of incubation of diluted root macerates plated on TSA as an indicator of bacterial invasion capacity in the presence or absence of nitrogen source. Numbers of $\mathrm{CFU} / \mathrm{mL}$ in the external rooting medium were also analyzed to determine bacterial viability in the presence or absence of a nitrogen source. Then colonies were picked, restreaked on TSA, and stocked in pure culture. For counting rhizoplane bacteria, roots were washed with sterile distilled water several times and subsequently immersed in $0.8 \%$ saline in a $125 \mathrm{~mL}$ Erlenmeyer, added with $3.0 \mathrm{~g}$ of glass beads and shaken at $200 \mathrm{rpm}$ for $30 \mathrm{~min}$, at $28^{\circ} \mathrm{C}$. The resulting supernatants were diluted and cultured on TSA, and bacterial growth observed after three-day incubation at $28^{\circ} \mathrm{C}$ was regarded as rhizoplane population.

2.3. In Vitro Screening of Reisolated Bacterial Isolates for Their PGP Activities. All strains, reisolated from inside roots of rice, were characterized for PGP traits. Production of siderophore, IAA, salicylic acid (SA), and HCN was determined according to the methodology described by Schwyn and Neilands [16], Patten and Glick [17], Meyer et al. [18], and Lorck [19], respectively, whereas all the isolates were screened for their phosphate-solubilizing ability on medium proposed by Sperber [20]. The ability of the isolates to produce ACC deaminase was also screened on minimal media containing ACC as their sole nitrogen source as described by Glick et al. [21].

2.4. In Vitro Antifungal Activity. Bacterial isolates were evaluated for their antifungal activity against fungal rice pathogens by dual culture assay as described by Jinantana and Sariah [22]. Fungal rice pathogens Fusarium proliferum, Fusarium verticillioides, Fusarium fujikuroi, Magnaporthe salvinii, and Magnaporthe grisea were kindly provided by laboratory of phytopathology, Department of plant protection, University of Tehran, Iran.

2.5. Extracellular Hydrolytic Enzymes Activity Assay. Chitinase activity was measured according to Jung and Kim [23]. Cellulase and pectinase activities were assayed on the indicator plates as described by Mateos et al. [24].

2.6. Efficient Establishment of Endophytic Colonization of Rice Plants by 9 Endophytes. Endophytic colonization of rice roots and assessment of their potential to promote plant growth were performed using the same procedures as described above, but, in this assay, the bacterial inocula were suspended in sterile Hoagland's medium containing $8 \mathrm{mM}$ $\left(\mathrm{NH}_{4}\right)_{2} \mathrm{SO}_{4}$ as single-strain inoculants. Shoot biomass (stem plus leaves) and root mass were measured as dry and fresh weights, respectively. In addition, root height was measured. Reisolation and viable plate counting of endophytic isolates populations were also carried out as described above.

2.7. Confirmation Test. Ten isolates isolated from berseem clover plant grown at field, which had been screened only based on the production of IAA, were retested, using the same procedures as described previously in order to confirm the efficiency of the bioassay. As additional negative controls, two IAA nonproducing isolates were also included.

2.8. Statistical Analysis. All the experiments were arranged in randomized complete design with four replications in each treatment and repeated twice. Analysis of variance (ANOVA) was performed, and means were compared by the Tukey test at $5 \%$ probability level using the SAS (V. 8) software package (SAS Institute, Cary, NC, USA).

\section{Results}

3.1. Isolation of Bacteria from Clover Root. A total of 200 bacterial strains were isolated from the rhizosphere $(120$ isolates) and surface-sterilized roots (80 isolates) of berseem clover grown in rotation with rice in region of Dashte Naz, Mazandaran, Iran. Colony and cell morphology and Gramstaining tests were performed on the isolates. $54 \%$ of the isolates were Gram positive, and the rest were Gram negative. No further attempts for identification were made. All isolates were used for detailed investigation.

3.2. Colonization of Rice Plants. To determine which of the endophytic bacteria had the ability to colonize and persist at high levels in two rice varieties, we carried out studies with a gnotobiotic system, using axenic rice plantlets. In all colonization studies, controls were included to verify that the inoculated bacteria were recovered. No bacteria could be isolated from noninoculated plants. All 200 isolates were inoculated as 10 mixtures of 20 strains each into the rice hosts and grown under gnotobiotic conditions. Of these, 34 strains (9 endophytes and 25 rhizoplane isolates) colonized the plants at levels ranging from 4.3 to $7.9 \log 10 \mathrm{CFU} / \mathrm{g}$ (fresh weight) at 20 days postinoculation (data not shown). The 34 isolates were all good root colonizers. The highest proportions of endophytes that were able to colonize the hosts were obtained from variety Hashemi grown in Hoagland $+\mathrm{N}$ growth medium (data not shown). The results indicated that none of the mixtures produced any disease symptoms or abnormalities in two rice varieties. Interestingly, 20 days after inoculation of the isolates in gnotobiotically cultured plantlets, the number of viable bacteria in the external rooting medium range in $10^{10} \mathrm{CFU}$, regardless the absence or presence of nitrogen. 
TABLE 1: Plant growth promoting activities of nine clover endophytic strains reisolated from the root interior of rice and twenty-five strains isolated from the rhizoplane of rice grown in gnotobiotic tube culture for 20 days.

\begin{tabular}{|c|c|c|c|c|c|c|c|c|c|c|}
\hline Isolate & $\begin{array}{l}\text { Siderophore } \\
\text { production }\end{array}$ & $\begin{array}{l}\text { Phosphorous } \\
\text { solubilization }\end{array}$ & $\begin{array}{c}\text { IAA } \\
\text { production } \\
\left(\mu \mathrm{gL}^{-1}\right)\end{array}$ & $\begin{array}{c}\mathrm{HCN} \\
\text { production }\end{array}$ & $\begin{array}{c}\text { ACC } \\
\text { deaminase } \\
\text { activity }\end{array}$ & $\begin{array}{c}\text { Chitinase } \\
\text { activity }\end{array}$ & $\begin{array}{l}\text { Pectinase } \\
\text { activity }\end{array}$ & $\begin{array}{l}\text { Cellulase } \\
\text { activity }\end{array}$ & $\begin{array}{c}\text { Salicylic } \\
\text { acid } \\
\text { production }\end{array}$ & $\begin{array}{l}\text { Antagonistic } \\
\text { to all of the } \\
\text { pathogens }\end{array}$ \\
\hline E1 & - & - & + & - & + & + & + & + & - & - \\
\hline E2 & - & + & + & - & + & - & + & + & - & - \\
\hline E3 & + & - & + & - & - & - & + & - & - & + \\
\hline E4 & + & + & + & + & - & - & - & + & - & - \\
\hline E5 & - & + & + & - & + & - & + & - & + & - \\
\hline E6 & + & + & + & - & - & - & + & + & - & + \\
\hline E7 & + & - & + & - & + & - & - & + & - & - \\
\hline E8 & + & - & + & + & - & - & + & + & - & - \\
\hline E9 & + & - & + & - & - & - & + & + & - & - \\
\hline $\mathrm{R} 1$ & - & + & + & - & + & - & + & - & - & - \\
\hline R2 & + & + & + & - & - & - & + & + & - & - \\
\hline R3 & + & + & + & - & - & - & + & + & - & - \\
\hline $\mathrm{R} 4$ & + & + & + & + & - & - & - & + & - & - \\
\hline R5 & + & + & + & - & + & - & - & + & - & - \\
\hline R6 & - & - & + & - & - & - & - & + & - & - \\
\hline R7 & + & - & + & - & - & - & - & + & - & - \\
\hline $\mathrm{R} 8$ & + & - & + & - & - & - & - & + & - & - \\
\hline R9 & + & - & + & + & + & - & - & + & + & + \\
\hline R10 & + & + & + & - & + & - & + & - & - & - \\
\hline R11 & + & - & + & - & - & - & + & - & - & - \\
\hline $\mathrm{R} 12$ & + & + & + & - & + & + & + & - & - & - \\
\hline $\mathrm{R} 13$ & + & - & + & - & - & - & - & - & - & - \\
\hline R14 & + & - & + & + & + & - & - & + & - & - \\
\hline $\mathrm{R} 15$ & + & - & + & - & + & - & + & + & + & - \\
\hline R16 & - & - & + & - & - & - & - & + & - & - \\
\hline R17 & - & - & + & + & + & + & - & + & - & - \\
\hline $\mathrm{R} 18$ & + & + & + & + & + & - & + & + & - & - \\
\hline R19 & + & - & + & - & - & - & + & + & - & + \\
\hline R20 & + & - & + & - & - & - & + & + & - & - \\
\hline R21 & + & + & + & - & + & - & + & + & - & - \\
\hline R22 & + & - & + & - & + & + & + & + & - & - \\
\hline R23 & + & + & + & - & - & - & + & - & - & - \\
\hline $\mathrm{R} 24$ & + & + & + & - & + & - & + & - & - & - \\
\hline R25 & + & - & + & - & - & - & + & - & - & - \\
\hline
\end{tabular}

-: represents no activity, + : represents activity.

$\mathrm{E}$ : represents isolates reisolated from the root interior of rice seedlings.

$\mathrm{R}$ : represents isolates reisolated from the rhizoplane of rice seedlings.

3.3. Plant Growth-Promoting Traits of Test Isolates. A total of 34 bacterial isolates were reisolated from the roots of two rice varieties under gnotobiotic conditions. When the bacterial isolates were evaluated for their plant growth-promoting traits, all isolates produced IAA, 27, 7, 16, 4, 22, 24, and three isolates produced siderophore, $\mathrm{HCN}, \mathrm{ACC}$ deaminase, chitinase, pectinase, cellulase, and SA, respectively, whereas 15 isolates solubilized phosphorous. 4 isolates inhibited the growth of fungal rice pathogens. Of the 9 isolates isolated from within rice plants, all isolates produced IAA, 6, 2, 4, 1, 6, 7 , and one isolate produced siderophore, HCN, ACC deaminase, chitinase, pectinase, cellulase, and SA, respectively, whereas 4 isolates solubilized phosphorous. Two isolates inhibited the growth of fungal rice pathogens in the dual culture assay (Table 1). The isolates produced IAA between 3 and $17 \mu \mathrm{g} \mathrm{mL}^{-1}$. 
3.4. Reapply the Endophytic Isolates in Single-Strain Inoculations. Efficient establishment of endophytic colonization of rice plants by 9 endophytes was demonstrated with a gnotobiotic system using axenic rice plantlets. Bacterial strains were successfully reisolated from roots of two rice varieties, and a considerably high recovery was recorded from rice plants of 20 days after inoculation. The average number of strains endophytically colonizing roots of Khazar and Hashemi varieties was, respectively, $7.5 \times 10^{6}$ and $2.6 \times 10^{7} \mathrm{CFU} / \mathrm{g}$ of fresh weight plantlet tissue. The influence of nitrogen fertilization in the experiments conducted with bacterial strains was performed with axenic plantlets cultured on Hoagland's solution supplemented with $8 \mathrm{Mm}\left(\mathrm{NH}_{4}\right)_{2} \mathrm{SO}_{4}$. Colonization extent was considerably higher in roots in presence of $\mathrm{N}$, compared to roots in absence of $\mathrm{N}$ (Table 2). Plantlets cultivated for 20 days in the presence of $\left(\mathrm{NH}_{4}\right)_{2} \mathrm{SO}_{4}$ showed a significant increase in bacterial invasion levels. Plating experiments of macerates from surface-sterilized roots of the inoculated plants indicated substantial populations of the endophytic bacteria, the magnitude of which varied the rice cultivar and the plant growth medium (Table 2). The inoculated roots appeared healthy without development of nodulelike hypertrophies or obvious symptoms of disease. Under these experimental conditions, internal root colonization by the isolates was not suppressed in Hoagland's plant growth medium, which contains $\mathrm{NH}_{4}{ }^{+}$as a source of $\mathrm{N}$. Colonization by the strains induced, in all inoculated plants, a large increase in root hair number and length. The colonization and growth-promoting the effects of nine IAA producing endophytic strains were compared in inoculated rice plantlets as single-strain inoculants. The presence of a higher number of lateral roots and more abundant root hairs was observed in response to colonization by the strains when compared with noninoculated plants. All the IAA producing isolates increased shoot dry mass by $22-44 \%$, root fresh mass by $8-$ $48 \%$, and root length by $3-52 \%$, over the control. The isolate E9 demonstrated to be the best plant growth-promoting bacteria, with an increase of $48 \%$ in root fresh weight and $44 \%$ in shoot dry weight as compared with control (Table 3 ). A significant relationship among IAA producing isolates, rate of root colonization, and plant growth was observed (Figures 1 and 2).

3.5. Confirmation Test. Screening to detect isolates with good potential as rice growth-promoting agents indicated that 7 of 10 endophytes, inoculated on rice varieties, were able to colonize within roots and promote plant growth (data not shown). According to the results obtained, 7 of 10 isolates tested (70\%) behaved as potentially good plant growth-promoting and colonizing agents. Seedlings inoculated with IAA producing isolates yielded more shoot biomass and colonization than the control plants inoculated with IAA nonproducing strains. Plants inoculated with both IAA producing isolates and other PGP traits producing isolates did not yield more biomass and colonization than plants inoculated with IAA producing isolates alone. Rate of colonization of rice plants with IAA Producing isolates showed that inoculation with the strains yielded a $10-20 \%$ increase in root weight as compared with
TABLE 2: CFU counts of endophytic bacteria colonizing internal part of roots of the Iranian rice variety grown in gnotobiotic tube culture for 20 days in Hoagland liquid with or without nitrogen $(8 \mathrm{mM}$ as $\left.\left(\mathrm{NH}_{4}\right)_{2} \mathrm{SO}_{4}\right)$.

\begin{tabular}{|c|c|c|c|}
\hline \multirow[t]{2}{*}{$\begin{array}{l}\text { Endophytic } \\
\text { isolate }\end{array}$} & \multirow[t]{2}{*}{$\begin{array}{l}\text { Plant growth medium } \\
\text { (Hoagland) }\end{array}$} & \multicolumn{2}{|c|}{$\begin{array}{l}\text { Rice endophyte population } \\
\text { (log } 10 \text { CFU/g root fresh wt) }\end{array}$} \\
\hline & & Khazar & Hashemi \\
\hline E1 & $+\mathrm{N}$ & 6.30 & 7.03 \\
\hline E2 & $+\mathrm{N}$ & 6.45 & 6.87 \\
\hline E3 & $+\mathrm{N}$ & 7.68 & 8.54 \\
\hline $\mathrm{E} 4$ & $+\mathrm{N}$ & 7.98 & 8.15 \\
\hline E5 & $+\mathrm{N}$ & 6.92 & 7.32 \\
\hline E6 & $+\mathrm{N}$ & 8.34 & 8.56 \\
\hline E7 & $+\mathrm{N}$ & 8.65 & 8.96 \\
\hline E8 & $+\mathrm{N}$ & 8.54 & 9.13 \\
\hline E9 & $+\mathrm{N}$ & 9.21 & 9.76 \\
\hline E1 & $-\mathrm{N}$ & 5.92 & 6.43 \\
\hline E2 & $-\mathrm{N}$ & 5.87 & 6.32 \\
\hline E3 & $-\mathrm{N}$ & 6.21 & 7.12 \\
\hline E4 & $-\mathrm{N}$ & 6.01 & 7.04 \\
\hline E5 & $-\mathrm{N}$ & 5.66 & 6.66 \\
\hline E6 & $-\mathrm{N}$ & 7.87 & 7.98 \\
\hline E7 & $-\mathrm{N}$ & 7.08 & 8.45 \\
\hline E8 & $-\mathrm{N}$ & 7.87 & 8.32 \\
\hline E9 & $-\mathrm{N}$ & 8.90 & 8.96 \\
\hline
\end{tabular}

the noninoculated control and IAA non producing isolates. Interestingly, IAA producing isolates developed higher culturable endophytic populations in the roots. In this study, a significant relationship among IAA producing isolates, rate of root colonization, and plant growth was also confirmed. The screening procedure appears to be very effective and less time consuming.

\section{Discussion}

To determine whether bacteria isolated from within clover plant tissue can have rice plant growth-promotion potential, colonize rice roots, and survive under flooded conditions, since rice is grown at such condition, seeds of two rice varieties were inoculated with individual bacterial isolates or mixtures of bacteria. We found IAA producing isolates that not only significantly improved rice plant growth but also, when used for colonization assay, significantly increased the rate of colonization than IAA nonproducing isolates (Figures 1 and 2). These results indicated that the endophytes had potential for promoting plant growth. Since the final aim after selecting the best isolate will be to introduce these isolates as a biofertilizer (suitable for pudding) for farmers, to find how much of chemical fertilizers (maximum yield) those bacteria can replace, we should select bacteria that have been isolated in the presence of $\mathrm{N}$. We inoculated rice plant with both endophytic isolates and rhizosphere isolates isolated from the clover roots because microfloral populations already resident 
TABLE 3: Evaluation of various morphological responses of rice (variety Hashemi) in gnotobiotic tube culture for 20 days in Hoagland liquid with nitrogen $\left(8 \mathrm{Mm}\right.$ as $\left.\left(\mathrm{NH}_{4}\right)_{2} \mathrm{SO}_{4}\right)$ after inoculation with nine endophytes.

\begin{tabular}{|c|c|c|c|}
\hline Isolate code & Root length $(\mathrm{cm})$ & Root fresh weight (mg) & Shoot dry weight $(\mathrm{mg})$ \\
\hline Control & $2.6 \pm 0.03^{g}$ & $2.50 \pm 0.06^{\mathrm{e}}$ & $27.16 \pm 0.2^{c}$ \\
\hline E1 & $2.7 \pm 0.07^{f}$ & $2.55 \pm 0.08^{\mathrm{e}}$ & $27.82 \pm 0.1^{c}$ \\
\hline E2 & $2.6 \pm 0.08^{g}$ & $2.58 \pm 0.04^{\mathrm{e}}$ & $27.93 \pm 0.3^{c}$ \\
\hline E3 & $3.6 \pm 0.08^{\mathrm{d}}$ & $2.74 \pm 0.09^{c}$ & $34.62 \pm 0.2^{\mathrm{b}}$ \\
\hline E4 & $3.2 \pm 0.05^{\mathrm{e}}$ & $2.78 \pm 0.04^{\mathrm{c}}$ & $34.29 \pm 0.4^{\mathrm{b}}$ \\
\hline E5 & $2.7 \pm 0.04^{\mathrm{f}}$ & $2.63 \pm 0.09^{d}$ & $27.80 \pm 0.4^{c}$ \\
\hline E6 & $3.6 \pm 0.06^{\mathrm{d}}$ & $2.82 \pm 0.07^{\mathrm{c}}$ & $36.18 \pm 0.7^{\mathrm{b}}$ \\
\hline E7 & $3.8 \pm 0.07^{\mathrm{c}}$ & $2.91 \pm 0.06^{\mathrm{b}}$ & $40.30 \pm 0.5^{\mathrm{a}}$ \\
\hline E8 & $3.9 \pm 0.05^{\mathrm{b}}$ & $3.74 \pm 0.04^{\mathrm{a}}$ & $40.85 \pm 0.5^{\mathrm{a}}$ \\
\hline E9 & $4.0 \pm 0.04^{\mathrm{a}}$ & $3.76 \pm 0.06^{\mathrm{a}}$ & $40.38 \pm .06^{\mathrm{a}}$ \\
\hline
\end{tabular}

In each column, values followed by the same letter are not significantly different as determined by Tukey's mean comparison test $(P \leq 0.05 ; n=4)$.

within the host plant may well influence and be influenced by rhizosphere bacteria $[25,26]$. In addition, several studies have reported that endophytic microbial communities originate from the soil and rhizosphere [27-29]. Since aseptic technique was used throughout, and the surface-sterilization procedure was considered effective, we may verify that the same bacteria inoculated to sterile rice seedlings could be reisolated from these seedlings (to fulfill Koch's postulate) and examine their endophytic competence (infection and persistence characteristics). 34 strains had colonized the plants at levels ranging from 4.3 to $7.9 \log 10 \mathrm{CFU} / \mathrm{g}$ (fresh weight) at 20 days after inoculation. The number of CFU of these bacteria in roots fell in the range of endophytic bacteria $[30,31]$. Interestingly, the endophytic isolates developed higher culturable endophytic populations in roots of varieties Hashemi than in those of varieties Khazar (Table 2). Thus, the degree to which endophytic isolates establish endophytic populations within rice varies among different varieties [12]. The establishment of plant growth promotion by rhizobia strains has been observed in crops such as wheat [32], rice [12], canola, lettuce [33], and sunflower [34, 35]. Colonization extent was considerably higher in roots in the presence of $\mathrm{N}$, compared to roots in the absence of $\mathrm{N}$ (Table 2). Plantlets cultivated for 20 days in the presence of $\left(\mathrm{NH}_{4}\right)_{2} \mathrm{SO}_{4}$ showed a significant increase in bacterial invasion levels. Muthukumarasamy et al. [36] showed that the $\mathrm{N}$-fertilization did not affect the diazotrophic bacterial population in all stages of growth of rice. Nitrogen alters the physiological state of the plant, and this subsequently affects its association with the bacterial population [37]. Sensitivity of many diazotrophic bacteria to nitrogen fertilizers could affect their endophytic ability $[38,39]$. But, we have demonstrated that nitrogen fertilization was not a limiting factor for the recovery of the strains from internal plant tissues. Mechanisms of plant growth promotion by plant-associated bacteria vary greatly and can be broadly categorized into direct and indirect effects. The biological role of endophytes in supplying nitrogen to their host plant has not yet been confirmed. Yanni et al. [12] showed that rice plants grown under $\mathrm{N}$-free conditions in gnotobiotic tube culture were not consistently increased in $\mathrm{N}$-content nor did they have detectable acetylene reduction activity when examined 32 days after inoculation with these rhizobia; hence, we did not study the ability of producing $\mathrm{N}$ fixation by this isolates. Phosphorus is the second most limiting mineral nutrient affecting terrestrial plant growth. Bacteria can solubilize inorganic and organic phosphates by different ways. $[1,40]$. In the present study since phosphorus existed in a soluble form (Hoagland's growth medium), the isolates do not have any role in solubilizing phosphate and subsequently rice plant growth. Many bacteria produce organic compounds, so-called siderophores. Siderophores are produced by PGPR under iron-limited conditions $[1$, 41]. Iron also existed in a soluble form in the used growth medium. So, the isolates do not have any role in making Fe available for rice seedlings and subsequently rice plant growth. Of 34 isolates evaluated for siderophore production in this study, 27 isolates produced siderophore, indicating probably the ability of producing siderphore as the second PGP traits for screening the isolates isolated from clover for rice PGP agents. Under flooding conditions, iron availability is higher due to the reduction of ferric oxide hydrate complexes, releasing the more soluble Fe (II) that can even be toxic for the rice roots. The role of siderphore producing endophytes is may be to capture $\mathrm{Fe}$ (III), generated by oxidation of Fe (II) in oxic microniches into the plant or in the rihzosphere, increasing the iron availability locally or to reduce $\mathrm{Fe}$ (II) toxicity towards the plant by accumulation of the sequestered metal into the bacterial cells [42]. Ethylene is a phytohormone that increases in plants when they are exposed to both abiotic and biotic environmental stress conditions. The most commonly observed mechanism that reduces levels of ethylene production is via the activity of bacterial ACC deaminase [1]. But in our study due to the presence of $\mathrm{NH}_{4}^{+}$as $\left(\mathrm{NH}_{4}\right)_{2} \mathrm{SO}_{4}$, none of the isolates was able to utilize ACC as sole nitrogen. Hence, the isolate also could not have had any role in producing rice seedlings [43]. Because bacterial endophytes colonize an ecological niche that is similar to that of plant pathogens, they could potentially benefit plant growth indirectly by competing with pathogens for space and nutrients, thus suppressing the growth or activity of these pathogens [1]. We also examined the potential of the isolates in inhibiting fungal rice 
pathogens. Since the rice seedlings have not been inoculated with fungal pathogens, the isolates could not have any role in rice seedlings growth. Many microorganisms produce and release lytic enzymes that can hydrolyze a wide variety of polymeric compounds, including chitin, proteins, cellulose, hemicellulose, and DNA [44]. When endophytes colonize on the plant surface, they produce enzymes to hydrolyze plant cell walls. As a result, these enzymes also have the function to suppress plant pathogen activities directly and have the capability of degrading the cell walls of fungi and oomycetes [45-47]. Several studies showed that production of cell wall degrading enzymes such as cellulase, phosphatase, or pectinase in PGPR was important in facilitating entry of the bacteria into the intercellular spaces of plant root hairs [48]. The present investigation also showed the presence of different levels of cellulase and pectinase activities in different isolates suggesting their potential for inter- and intracellular colonization. But the cellulase and pectinase activities of the inoculated strain did not affect the growth or health of the seedlings [49]. Systemic acquired resistance (SAR) induced by pathogen infection is mediated by salicylic acid and associated with the accumulation of pathogenesis-related (PR) proteins [50]. In the study, one of 9 endophytes produced SA, and there is no relationship between rice growth and SA producing isolates [51]. Indole-3-acetic acid (IAA), the most studied phytohormone produced by plant-associated bacteria, contributes to plant growth and development by increasing root growth and root length and has also been associated with proliferation and elongation of root hairs. Our results showed that there is a significant relationship among IAA producing isolates, the rate of root colonization, and plant growth (Figures 1 and 2). An alternative working hypothesis is that endophytic colonization by these native isolates modulates growth physiology of rice (possibly by hormone action) enabling the plant root system to utilize the existing resources of available nutrients and water more efficiently in ways that may be independent of biological $\mathrm{N}_{2}$ fixation [12]. IAA producing endophytes reisolated from the surface sterilized roots of rice appear to be very competent plant growth-promoting endophytes. Our findings are consistent with earlier reports where similar trend was reported in different bacteria [52-57]. Since The initial step of bacteria invasion in plant root consists of the attachment of bacteria onto epidermal cells of the root surface, where root hair zone represents one of the major sites of primary colonization, mainly on the basal region of emerging hairs, it is possible that IAA producing strains by increased root system can colonize plant roots better than other strains. The role of bacterial IAA in different microorganism-plant interactions highlights the fact that bacteria use this phytohormone to interact with plants as a part of their colonization strategy, including phytostimulation and circumvention of basal plant defense mechanisms [58]. Results obtained by in vitro screenings for the assessment of bacterial PGP cannot fully reflect the reality, for example, at the field or in the greenhouse. However, in vitro screenings for bacterial PGP can provide a tool to select strains out of the vast amount of bacteria living in plant-associated habitats that fulfill in situ what they promise in vitro [53]. The findings described here represent

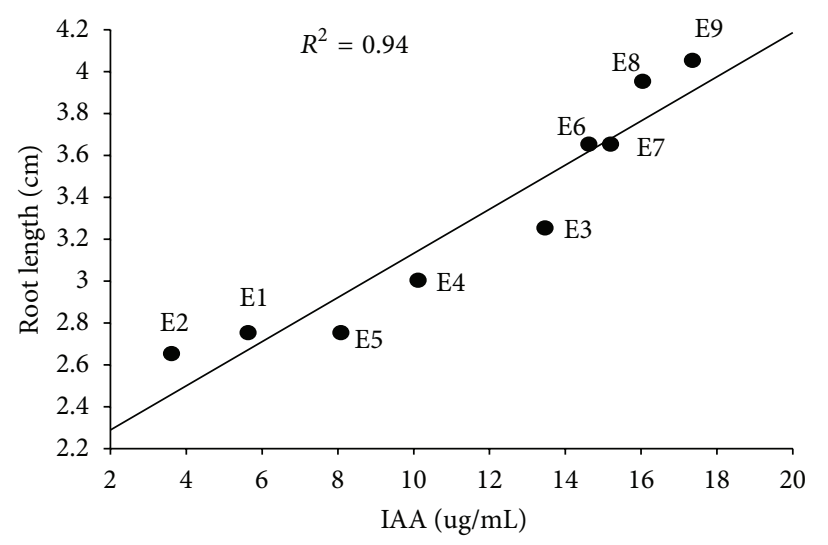

FIGURE 1: Correlation between IAA producing isolates with root length by nine endophytic isolates reisolated from rice 20 days after inoculation under gnotobiotic conditions.

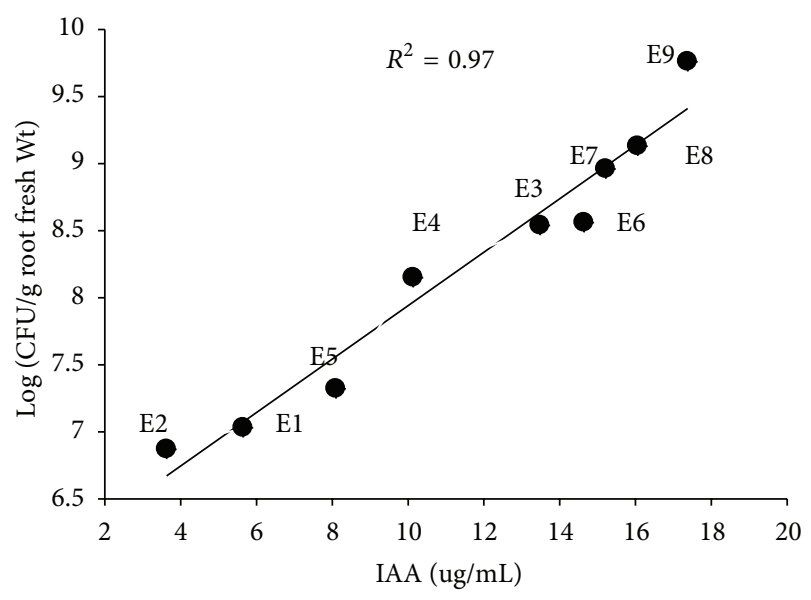

FIGURE 2: Correlation between IAA producing isolates with the size of population by nine endophytic isolates reisolated from rice 20 days after inoculation under gnotobiotic conditions.

a step forward in achieving the technically challenging goal of increasing rice productivity and screening superior bacteria by reducing its dependence of the need for fertilizer-N through enhancement of its natural association with rhizobia without requiring as a highly developed system as the root nodule rhizobium-legume symbiosis.

\section{Conclusion}

IAA production confers to bacteria competitive advantages to colonize plant tissues. Bacterial IAA loosens plant cell walls and as a result facilitates an increasing amount of root exudation that provides additional nutrients to support the growth of rhizosphere bacteria. The screening procedure appears to be very effective and less time consuming. Therefore, proper screening of rice growth-promoting bacteria can be useful for future agricultural applications, providing higher production yields, reduced input costs, and negative environmental impact due to the use of nitrogen fertilizers. 


\section{Acknowledgment}

The authors wish to thank the chairman of the Department of Soil Science of Tehran University, Iran, for providing the necessary facilities for this study.

\section{References}

[1] N. Weyens, D. Van der Lelie, S. Taghavi, L. Newman, and J. Vangronsveld, "Exploiting plant-microbe partnerships to improve biomass production and remediation," Trends in Biotechnology, vol. 27, no. 10, pp. 591-598, 2009.

[2] R. P. Ryan, K. Germaine, A. Franks, D. J. Ryan, and D. N. Dowling, "Bacterial endophytes: recent developments and applications," FEMS Microbiology Letters, vol. 278, no. 1, pp. 1-9, 2008.

[3] S. Lee, M. Flores-Encarnación, M. Contreras-Zentella, L. Garcia-Flores, J. E. Escamilla, and C. Kennedy, "Indole-3-acetic acid biosynthesis is deficient in Gluconacetobacter diazotrophicus strains with mutations in cytochrome c biogenesis genes," Journal of Bacteriology, vol. 186, no. 16, pp. 5384-5391, 2004.

[4] S. A. Wakelin, R. A. Warren, P. R. Harvey, and M. H. Ryder, "Phosphate solubilization by Penicillium spp. closely associated with wheat roots," Biology and Fertility of Soils, vol. 40, no. 1, pp. 36-43, 2004.

[5] M. E. Will and D. M. Sylvia, "Interaction of rhizosphere bacteria, fertilizer, and vesicular-arbuscular mycorrhizal fungi with sea oats," Applied and Environmental Microbiology, vol. 56, no. 7, pp. 2073-2079, 1990.

[6] J. M. Costa and J. E. Loper, "Characterization of siderophore production by the biological control agent Enterobacter cloacae," Molecular Plant-Microbe Interactions, vol. 7, no. 4, pp. 440-448, 1994.

[7] B. Rodelas, V. Salmerón, M. V. Martinez-Toledo, and J. González-López, "Production of vitamins by Azospirillum brasilense in chemically-defined media," Plant and Soil, vol. 153, no. 1, pp. 97-101, 1993.

[8] K. Clay, "Effects of fungal endophytes on the seed and seedling biology of Lolium perenne and Festuca arundinacea," Oecologia, vol. 73, no. 3, pp. 358-362, 1987.

[9] V. J. Kevin, "Plant growth promoting rhizobacteria as biofertilizers," Plant and Soil, vol. 255, no. 2, pp. 571-586, 2003.

[10] D. P. Belesky and D. P. Malinowski, "Abiotic stresses and morphological plasticity and chemical adaptations of Neotyphodium-infected tall fescue plants; in Microbial endophytes," C. W. Bacon and J. F. White Jr., Eds., pp. 455-484, Marcel Dekker, New York, NY, USA, 2000.

[11] H. Antoun, C. J. Beauchamp, N. Goussard, R. Chabot, and R. Lalande, "Potential of Rhizobium and Bradyrhizobium species as plant growth promoting rhizobacteria on non-legumes: effect on radishes (Raphanus sativus L.)," Plant and Soil, vol. 204, no. 1, pp. 57-67, 1998.

[12] Y. G. Yanni, R. Y. Rizk, V. Corich et al., "Natural endophytic association between Rhizobium leguminosarum bv. trifolii and rice roots and assessment of its potential to promote rice growth," Plant and Soil, vol. 194, no. 1-2, pp. 99-114, 1997.

[13] H. S. Alves Silva, R. Da Silva Romeiro, and A. Mounteer, "Development of a root colonization bioassay for rapid screening of rhizobacteria for potential biocontrol agents," Journal of Phytopathology, vol. 151, no. 1, pp. 42-46, 2003.
[14] J. W. Kloepper, "Plant growth-promoting rhizobacteria (other systems)," in Azospirillum/Plant Associations, Y. Okon, Ed., pp. 137-166, CRC Press, Boca Raton, Fla, USA, 1997.

[15] A. V. Sturz, B. R. Christie, B. G. Matheson, and J. Nowak, "Biodiversity of endophytic bacteria which colonize red clover nodules, roots, stems and foliage and their influence on host growth," Biology and Fertility of Soils, vol. 25, no. 1, pp. 13-19, 1997.

[16] B. Schwyn and J. B. Neilands, "Universal chemical assay for the detection and determination of siderophores," Analytical Biochemistry, vol. 160, no. 1, pp. 47-56, 1987.

[17] C. L. Patten and B. R. Glick, "Bacterial biosynthesis of indole3-acetic acid," Canadian Journal of Microbiology, vol. 42, no. 3, pp. 207-220, 1996.

[18] J.-M. Meyer, P. Azelvandre, and C. Georges, "Iron metabolism in Pseudomonas: salicylic acid, a siderophore of Pseudomonas fluorescens CHA0," BioFactors, vol. 4, no. 1, pp. 23-27, 1992.

[19] H. Lorck, "Production of hydrocyanic acid by bacteria," Physiol Plant, vol. 1, pp. 142-146, 1948.

[20] J. I. Sperber, "The incidence of apatite-solubilizing organisms in the rhizosphere and soil," Australian Journal of Agricultural Research, vol. 9, no. 6, pp. 778-781, 1995.

[21] B. R. Glick, D. M. Karaturovic, and P. C. Newell, "A novel procedure for rapid isolation of plant growth promoting pseudomonads," Canadian Journal of Microbiology, vol. 41, no. 6, pp. 533-536, 1995.

[22] J. Jinantana and M. Sariah, "Antagonistic effect of Malaysian isolates of Trichoderma harzianum and Gliocladium virens on Sclerotium rolfsii," Pertanika Journal of Tropical Agricultural Science, vol. 20, pp. 35-41, 1997.

[23] K.-H. Jung and H. J. Kim, "Development of an agar diffusion method to measure elastase inhibition activity using ElastinCongo red," Journal of Microbiology and Biotechnology, vol. 16, no. 8, pp. 1320-1324, 2006.

[24] P. F. Mateos, J. I. Jimenez-Zurdo, J. Chen et al., "Cell-associated pectinolytic and cellulolytic enzymes in Rhizobium leguminosarum biovar trifolii," Applied and Environmental Microbiology, vol. 58, no. 6, pp. 1816-1822, 1992.

[25] J. H. Li, E. T. Wang, W. F. Chen, and W. X. Chen, "Genetic diversity and potential for promotion of plant growth detected in nodule endophytic bacteria of soybean grown in Heilongjiang province of China," Soil Biology and Biochemistry, vol. 40, no. 1, pp. 238-246, 2008.

[26] P. Nejad and P. A. Johnson, "Endophytic bacteria induce growth promotion and wilt disease suppression in oilseed rape and tomato," Biological Control, vol. 18, no. 3, pp. 208-215, 2000.

[27] M. Elvira-Recuenco and J. W. L. Van Vuurde, "Natural incidence of endophytic bacteria in pea cultivars under field conditions," Canadian Journal of Microbiology, vol. 46, no. 11, pp. 1036-1041, 2000.

[28] J. Hallmann, A. Quadt-Hallmann, W. F. Mahaffee, and J. W. Kloepper, "Bacterial endophytes in agricultural crops," Canadian Journal of Microbiology, vol. 43, no. 10, pp. 895-914, 1997.

[29] A. V. Sturz, B. R. Christie, and J. Nowak, "Bacterial endophytes: potential role in developing sustainable systems of crop production," Critical Reviews in Plant Sciences, vol. 19, no. 1, pp. 1-30, 2000.

[30] L. L. Wang, E. T. Wang, J. Liu, Y. Li, and W. X. Chen, "Endophytic occupation of root nodules and roots of Melilotus dentatus by Agrobacterium tumefaciens," Microbial Ecology, vol. 52, no. 3, pp. 436-443, 2006. 
[31] A. M. Abdel Wahab, H. H. Zahran, and M. H. Abd-Alla, "Roothair infection and modulation of four grain legumes as affected by the form and the application time of nitrogen fertilizer," Folia Microbiologica, vol. 41, no. 4, pp. 303-308, 1996.

[32] K. V. B. R. Tilak, N. Ranganayaki, K. K. Pal et al., "Diversity of plant growth and soil health supporting bacteria," Current Science, vol. 89, no. 7, pp. 869-885, 2005.

[33] T. C. Noel, C. Sheng, C. K. Yost, R. P. Pharis, and M. F. Hynes, "Rhizobium leguminosarum as a plant growth-promoting rhizobacterium: direct growth promotion of canola and lettuce," Canadian Journal of Microbiology, vol. 42, no. 3, pp. 279-283, 1996.

[34] Y. Alami, W. Achouak, C. Marol, and T. Heulin, "Rhizosphere soil aggregation and plant growth promotion of sunflowers by an exopolysaccharide-producing Rhizobium sp. strain isolated from sunflower roots," Applied and Environmental Microbiology, vol. 66, no. 8, pp. 3393-3398, 2000.

[35] K. A. Mattos, V. L. M. Pádua, A. Romeiro et al., "Endophytic colonization of rice (Oryza sativa L.) by the diazotrophic bacterium Burkholderia kururiensis and its ability to enhance plant growth," Anais da Academia Brasileira de Ciencias, vol. 80, no. 3, pp. 477-493, 2008.

[36] R. Muthukumarasamy, G. Revathi, and C. Lakshminarasimhan, "Influence of $\mathrm{N}$ fertilisation on the isolation of Acetobacter diazotrophicus and Herbaspirillum spp. from Indian sugarcane varieties," Biology and Fertility of Soils, vol. 29, no. 2, pp. 157-164, 1999.

[37] J. Prakamhang, K. Minamisawa, K. Teamtaisong, N. Boonkerd, and N. Teaumroong, "The communities of endophytic diazotrophic bacteria in cultivated rice (Oryza sativa L.)," Applied Soil Ecology, vol. 42, no. 2, pp. 141-149, 2009.

[38] V. M. Reis, J. I. Baldani, V. L. D. Baldani, and J. Dobereiner, "Biological dinitrogen fixation in Gramineae and palm trees," Critical Reviews in Plant Sciences, vol. 19, no. 3, pp. 227-247, 2000.

[39] L. E. Fuentes-Ramirez, T. Jimenez-Salgado, I. R. AbarcaOcampo, and J. Caballero-Mellado, "Acetobacter diazotrophicus, an indoleacetic acid producing bacterium isolated from sugarcane cultivars of México," Plant and Soil, vol. 154, no. 2, pp. 145-150, 1993.

[40] B. E. Ramey, M. Koutoudis, S. B. Vonbodman, and C. Fuqa, "Biofilm formation in plant microbe associations," Current Opinion in Microbiology, vol. 7, pp. 602-609, 2004.

[41] J. Kuklinsky-Sobral, W. L. Araújo, R. Mendes, I. O. Geraldi, A. A. Pizzirani-Kleiner, and J. L. Azevedo, "Isolation and characterization of soybean-associated bacteria and their potential for plant growth promotion," Environmental Microbiology, vol. 6, no. 12, pp. 1244-1251, 2004.

[42] I. Loaces, L. Ferrando, and A. F. Scavino, "Dynamics, diversity and function of endophytic siderophore-producing bacteria in rice," Microbial Ecology, vol. 61, no. 3, pp. 606-618, 2011.

[43] E. Dell'Amico, L. Cavalca, and V. Andreoni, "Analysis of rhizobacterial communities in perennial Graminaceae from polluted water meadow soil, and screening of metal-resistant, potentially plant growth-promoting bacteria," FEMS Microbiology Ecology, vol. 52, no. 2, pp. 153-162, 2005.

[44] A. A. Belimov, V. I. Safronova, T. A. Sergeyeva et al., "Characterization of plant growth promoting rhizobacteria isolated from polluted soils and containing 1-aminocyclopropane-1carboxylate deaminase," Canadian Journal of Microbiology, vol. 47, no. 7, pp. 642-652, 2001.
[45] S. Tripathi, S. Kamal, I. Sheramati, R. Oelmuller, and A. Varma, "Mycorrhizal fungi and other root endophytes as biocontrol agents against root pathogens," Mycorrhiza, vol. 3, pp. 281-306, 2008.

[46] T. Andro, J. P. Chambost, and A. Kotoujansky, "Mutants of Erwinia chrysanthemi defective in secretion of pectinase and cellulase," Journal of Bacteriology, vol. 160, no. 3, pp. 1199-1203, 1984.

[47] K. E. Germaine, G. Keogh, B. Garcia-Cabellos et al., "Colonisation of poplar trees by gfp expressing bacterial endophytes," FEMS Microbiology Ecology, vol. 48, no. 1, pp. 109-118, 2004.

[48] R. M. Teather and P. J. Wood, "Use of Congo red-polysaccharide interactions in enumeration and characterization of cellulolytic bacteria from the bovine rumen," Applied and Environmental Microbiology, vol. 43, no. 4, pp. 777-780, 1982.

[49] P. F. Mateos, D. L. Baker, M. Petersen et al., "Erosion of root epidermal cell walls by Rhizobium polysaccharide-degrading enzymes as related to primary host infection in the Rhizobiumlegume symbiosis," Canadian Journal of Microbiology, vol. 47, no. 6, pp. 475-487, 2001.

[50] P. Mylona, K. Pawlowski, and T. Bisseling, "Symbiotic nitrogen fixation," Plant Cell, vol. 7, no. 7, pp. 869-885, 1995.

[51] V. Ramamoorthy, R. Viswanathan, T. Raguchander, V. Prakasam, and R. Samiyappan, "Induction of systemic resistance by plant growth promoting rhizobacteria in crop plants against pests and diseases," Crop Protection, vol. 20, no. 1, pp. $1-11,2001$.

[52] R. F. White, "Acetylsalicylic acid (aspirin) induces resistance to tobacco mosaic virus in tobacco," Virology, vol. 99, no. 2, pp. 410-412, 1979.

[53] F. Chi, S.-H. Shen, H.-P. Cheng, Y.-X. Jing, Y. G. Yanni, and F. B. Dazzo, "Ascending migration of endophytic rhizobia, from roots to leaves, inside rice plants and assessment of benefits to rice growth physiology," Applied and Environmental Microbiology, vol. 71, no. 11, pp. 7271-7278, 2005.

[54] F. Ahmad, I. Ahmad, and M. S. Khan, "Screening of free-living rhizospheric bacteria for their multiple plant growth promoting activities," Microbiological Research, vol. 163, no. 2, pp. 173-181, 2008.

[55] R. Mendes, A. A. Pizzirani-Kleiner, W. L. Araujo, and J. M. Raaijmakers, "Diversity of cultivated endophytic bacteria from sugarcane: genetic and biochemical characterization of Burkholderia cepacia complex isolates," Applied and Environmental Microbiology, vol. 73, no. 22, pp. 7259-7267, 2007.

[56] R. H. Chabot, H. Antoun, J. W. Kloepper, and C. J. Beauchamp, "Root colonization of maize and lettuce by bioluminescent Rhizobium leguminosarum biovar phaseoli," Applied and Environmental Microbiology, vol. 62, no. 8, pp. 2767-2772, 1996.

[57] M. Fürnkranz, H. Müller, and G. Berg, "Characterization of plant growth promoting bacteria from crops in Bolivia," Journal of Plant Diseases and Protection, vol. 116, no. 4, pp. 149-155, 2009.

[58] S. Spaepen, J. Vanderleyden, and R. Remans, "Indole-3-acetic acid in microbial and microorganism-plant signaling," FEMS Microbiology Reviews, vol. 31, no. 4, pp. 425-448, 2007. 

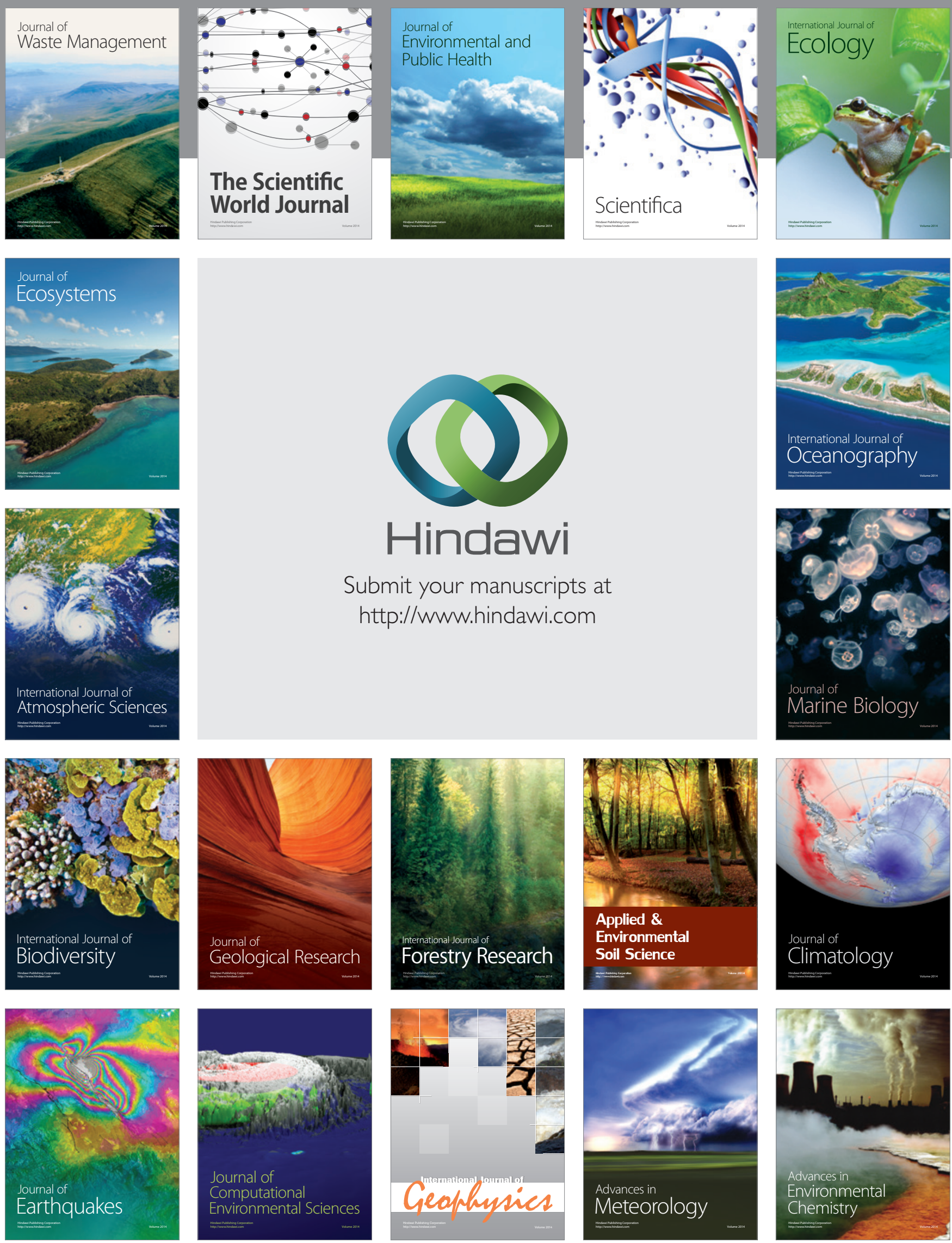